This is the accepted manuscript of the article, which has been published in Journal of Breath Research. https://doi.org/10.1088/1752-7163/ab4784

\title{
Repeatability and variation of the flow independent nitric oxide parameters
}

\author{
Tuomas Karvonen $^{1}$ and Lauri Lehtimäki ${ }^{1,2}$ \\ ${ }^{1}$ Faculty of Medicine and Health Technology, Tampere University, Tampere, Finland \\ ${ }^{2}$ Allergy Centre, Tampere University Hospital, Tampere, Finland \\ Email: $\underline{\text { lauri.lehtimaki@tuni.fi }}$
}

\begin{abstract}
Introduction: Fractional exhaled nitric oxide $\left(\mathrm{F}_{\mathrm{E}} \mathrm{NO}\right)$ is a non-invasive marker of airway inflammation. Measuring $\mathrm{F}_{\mathrm{E}} \mathrm{NO}$ at several flow rates enables the calculation of flow independent NO-parameters (alveolar NO concentration $\left(\mathrm{C}_{\mathrm{A}} \mathrm{NO}\right)$, bronchial flux of $\mathrm{NO}\left(\mathrm{J}_{\mathrm{aw}} \mathrm{NO}\right)$, bronchial mucosal $\mathrm{NO}$ concentration $\left(\mathrm{C}_{\mathrm{aw}} \mathrm{NO}\right)$ and bronchial wall NO diffusion capacity $\left(\mathrm{D}_{\mathrm{aw}} \mathrm{NO}\right)$ ) that are capable of partitioning the source and release mechanism of NO from the lower respiratory tract. However, the current literature on repeatability and normal variation of the NO-parameters is deficient, and this information is needed to develop the method towards clinical use.

Methods: We calculated NO-parameters in altogether 28 healthy subjects using two different mathematical methods and used three different study protocols to investigate: (i) repeatability of two consecutive measurements of NO parameters, (ii) within-day variation of the NO-parameters over one working day and (iii) day-to-day variation of the NO-parameters between consecutive days during course of a working week.

Results: $\mathrm{J}_{\mathrm{aw}} \mathrm{NO}$ was the most repeatable among the NO-parameters, whereas $\mathrm{D}_{\mathrm{aw}} \mathrm{NO}$ and $\mathrm{C}_{\mathrm{aw}} \mathrm{NO}$ were notably least repeatable. $\mathrm{C}_{\mathrm{A}} \mathrm{NO}$ was higher during the second consecutive measurement (1.22 vs $1.57 \mathrm{ppb}, \mathrm{p}=0.017$ ). Both investigated mathematical methods yielded equally repeatable results. $\mathrm{J}_{\mathrm{aw}} \mathrm{NO}$ was slightly higher in the afternoon compared to morning (716 vs $881 \mathrm{pl} / \mathrm{s}, \mathrm{p}=0.01$ ), but other parameters showed no diurnal variation. Upper $95 \%$ limit for the day-to-day difference in the parameters in healthy subjects was about $1.2 \mathrm{ppb}$ in $\mathrm{C}_{\mathrm{A}} \mathrm{NO}, 400 \mathrm{pl} / \mathrm{s}$ in $\mathrm{J}_{\mathrm{aw}} \mathrm{NO}, 92 \mathrm{ppb}$ in $\mathrm{C}_{\mathrm{aw}} \mathrm{NO}$ and $16 \mathrm{pl} / \mathrm{s} / \mathrm{ppb}$ in $\mathrm{D}_{\mathrm{aw}} \mathrm{NO}$.

Conclusions: This is the first study assessing short-time repeatability of the NO-parameters. Repeatability of the NO-parameters was good and day-to-day variation in NO-parameters was quite low. We recommend scheduling $\mathrm{F}_{\mathrm{E}} \mathrm{NO}$-measurements at the same time of day, if possible, and in clinical use variation in NOparameters above the normal limits found is this study suggest changes in diseases activity.
\end{abstract}




\section{Introduction}

Measuring fraction of exhaled nitric oxide $\left(\mathrm{F}_{\mathrm{E}} \mathrm{NO}\right)$ is widely studied and standardized $[1,2]$ with official guidelines on its clinical use in diagnosis, monitoring and management of asthma [3,4]. Usually, $\mathrm{F}_{\mathrm{E}} \mathrm{NO}$ is measured at flow rate of $50 \mathrm{ml} / \mathrm{s}\left(\mathrm{F}_{\mathrm{E}} \mathrm{NO}_{50}\right)$. However, $\mathrm{F}_{\mathrm{E}} \mathrm{NO}$ measured at a single flow rate does not tell the source of exhaled NO within the lower respiratory tract. Tsoukias \& George introduced a two-compartment model of NO exchange dynamics of the lungs which is capable of partitioning the source and release mechanism of $\mathrm{NO}$ from the lower respiratory tract [5] if $\mathrm{F}_{\mathrm{E}} \mathrm{NO}$ is measured at multiple flow rates (extended $\mathrm{F}_{\mathrm{E}} \mathrm{NO}$-measurement, $\mathrm{eF}_{\mathrm{E}} \mathrm{NO}$-measurement). They also introduced a robust method of estimating alveolar $\mathrm{NO}$ concentration $\left(\mathrm{C}_{\mathrm{A}} \mathrm{NO}, \mathrm{ppb}\right)$ and bronchial $\mathrm{NO}$ flux $\left(\mathrm{J}_{\mathrm{aw}} \mathrm{NO}, \mathrm{pl} / \mathrm{s}\right)$ by calculating slope and intercept, respectively, of a linear regression line between NO output and exhalation flow rate (T\&G-method) [6]. This method is a linear approximation of the two-compartment model's non-linear equation and applies only with higher flow rates. Only methods using the non-linear equation of the two-compartment model allow calculation of bronchial mucosal NO concentration ( $\left.\mathrm{C}_{\mathrm{aw}} \mathrm{NO}, \mathrm{ppb}\right)$ and airway diffusing capacity of $\mathrm{NO}\left(\mathrm{D}_{\mathrm{aw}} \mathrm{NO}, \mathrm{pl} / \mathrm{s} / \mathrm{ppb}\right)$ and hence the release mechanism of NO from the lower respiratory tract [7]. Högman and Meriläinen introduced a simple iteration method based on three flow rates to allow calculation of $\mathrm{C}_{\mathrm{aw}} \mathrm{NO}$ and $\mathrm{D}_{\mathrm{aw}} \mathrm{NO}$ [8]. These two methods have been recommended by the latest technical standard on $\mathrm{F}_{\mathrm{E}} \mathrm{NO}$ [1].

Extended $\mathrm{F}_{\mathrm{E}} \mathrm{NO}$-measurement has been investigated for two decades, but there is still no clear consensus on all the technical aspects. NO-parameters calculated based on $\mathrm{eF}_{\mathrm{E}} \mathrm{NO}$-measurement are known to vary depending on mathematical method and flow rates used [9,10], making the comparison of different research groups' results challenging. In addition, repeatability and normal variation of the NO-parameters over time are still to be better assessed. The terms repeatability, reproducibility and variation are not always used coherently in literature. Repeatability refers to agreement between results of two successive measurements carried under the same conditions of measurement while variation refers to difference in two measurements where the cause of difference is change in the measured object rather than error in measurement technique.

To our knowledge, the current literature on $\mathrm{eF}_{\mathrm{E}} \mathrm{NO}$ lacks studies assessing repeatability. There are some publications on within-day variation [11-13] but sample sizes are relatively small and results from both healthy and diseased subjects are combined in some studies. Day-to-day variation has been investigated between two consecutive days or two days with a longer interval [10-12,14-17], but there are no studies measuring NOparameters on daily basis for several days consecutively. Knowledge on the repeatability of the measuring method and normal variation of $\mathrm{NO}$ parameters is of great importance for the development of $\mathrm{eF}_{\mathrm{E}} \mathrm{NO}$ measurement towards clinical applications, as it helps judging whether certain degree of change in NO parameters of a patient reflect changes in disease state or merely normal variation.

The purpose of this study was to determine the repeatability of $\mathrm{eF}_{\mathrm{E}} \mathrm{NO}$-measurement and normal variation over time of the NO-parameters. This study had three different study protocols to investigate: (i) repeatability of two consecutive $\mathrm{eF}_{\mathrm{E}} \mathrm{NO}$-measurements, (ii) within-day variation of the NO-parameters over one working day and (iii) day-to-day variation of the NO-parameters between consecutive days in course of a working week.

\section{Methods}

\section{Subjects}

All subjects were adults (over 18 years), non-smoking and healthy with regard to respiratory diseases and free of respiratory tract infections for at least 4 weeks. Subjects were asked not to eat, drink caffeinated beverages or heavily exercise within one hour prior the measurements. All subjects gave their written informed consent and the study was approved by the ethics committee of Tampere University Hospital (R17076).

\section{Extended $\mathrm{F}_{\mathrm{E}} \mathrm{NO}$-measurement}

$\mathrm{F}_{\mathrm{E}} \mathrm{NO}$ was measured using an ozone-chemiluminescence analyzer (NOA 280, Sievers Instruments, Boulder, CO, USA). The analyzer was calibrated daily by using calibration gas with known NO concentration of 20.5 ppm (AGA, Lidingö, Sweden). Zero-calibration was run daily using filtered NO-free air. Both calibrations 
were repeated twice successively. Computer controlled flow restrictor was calibrated before every subject at flow rates of 100 and $300 \mathrm{ml} / \mathrm{s}$ by using a $3 \pm 0.03$-liter syringe. Subjects were asked to flush their mouth and pharynx with water prior the measurements. Subjects were in a sitting position and were instructed to inhale through mouth to total lung capacity and then exhale through the mouthpiece steadily. Mouthpiece with a bacterial filter was connected to a computer-controlled flow restrictor [18]. The device measures flow rate in real-time and adjusts flow resistance to either increase or decrease the flow towards the target level to adjust for changes in the subjects' exhalation effort as long as the mouth pressure remained between 5 and $20 \mathrm{cmH}_{2} \mathrm{O}$ [19]. Subjects received visual feedback on mouth pressure on a computer screen and were asked to keep the pressure steady between 5 and $20 \mathrm{cmH}_{2} \mathrm{O}$. Researcher followed the $\mathrm{F}_{\mathrm{E}} \mathrm{NO}$ vs time -curve in real time and instructed the subject to maintain the mouth pressure steady until the curve had reached a steady plateau or the subject was run out of breath. NO concentration was then read from the plateau and the same flow rate was repeated. If a steady plateau was not reached, the subject was allowed to attempt the flow rate third time. If still no steady plateau was formed, the flow rate was discarded from the analysis. $\mathrm{F}_{\mathrm{E}} \mathrm{NO}$-measurement was performed at eight different flow rates: 10, 20, 30, 50, 100, 200, 300 and $400 \mathrm{ml} / \mathrm{s}$. FENO was measured 2-3 times at every flow rate and mean $\mathrm{F}_{\mathrm{E}} \mathrm{NO}$ at each flow rate was calculated and used as the result. Ambient air NO-concentration was measured prior every subject.

The method of Tsoukias \& George (T\&G) was used on $\mathrm{F}_{\mathrm{E}} \mathrm{NO}$ values at flow rates 100-400 ml/s to calculate $\mathrm{J}_{\mathrm{aw}} \mathrm{NO}$ and $\mathrm{C}_{\mathrm{A}} \mathrm{NO}$. The linearity of NO-output vs flow rate at flows $\geq 100 \mathrm{ml} / \mathrm{s}$ was evaluated and correlation factor $r<0.9$ was used as an exclusion criterion. Högman \& Meriläinen -algorithm (HMA) based on flow rates of 10,100 and $400 \mathrm{ml} / \mathrm{s}$ and was used to calculate $\mathrm{J}_{\mathrm{aw}} \mathrm{NO}, \mathrm{C}_{\mathrm{A}} \mathrm{NO}, \mathrm{C}_{\mathrm{aw}} \mathrm{NO}$ and $\mathrm{D}_{\mathrm{aw}} \mathrm{NO}$ [20]. HMA has a builtin quality control and as a further quality control, $\mathrm{C}_{\mathrm{A}} \mathrm{NO}$-values below zero and $\mathrm{C}_{\mathrm{aw}} \mathrm{NO}>1000 \mathrm{ppb}$ were excluded.

\section{Study protocols and analyses}

\section{Short-term repeatability of two consecutive $\mathrm{eF}_{\mathrm{E}} \mathrm{NO}$-measurements}

Two $\mathrm{eF}_{\mathrm{E}} \mathrm{NO}$-measurements were performed with only a short few minute break between the measurements if needed. NO-parameters were calculated using both HMA and T\&G methods. Repeatability of each NOparameter was assessed by three ways: calculating coefficient of repeatability (CR), calculating within-subject coefficient of variation (CV) and by assessing upper and lower 95\% limits of agreement between the first and second measurement by Bland-Altman plots. CR describes the confidence interval where the absolute difference between two repeated measurements is expected to lie with 95\% probability and was calculated as $C R=1.96 \sqrt{\frac{\sum(d 2-d 1)^{2}}{n}}$, where $\mathrm{d} 1$ is the first and $\mathrm{d} 2$ the second measurement and $\mathrm{n}$ is the number of subjects [21]. CV was calculated as CV = within-subject SD / within-subject mean, where SD is standard deviation. We also analyzed differences between group means or medians of the NO parameters from two consecutive $\mathrm{eF}_{\mathrm{E}} \mathrm{NO}$-measurements by using paired t-test or Wilcoxon's signed-rank test. To compare the repeatability of the two used methods (T\&G and HMA), the CV-values for these methods were compared by paired t-test or Wilcoxon’s signed-rank test.

\section{Within-day variation of the NO-parameters during working day}

Within-day variation of the NO-parameters during a working day was investigated by measuring $\mathrm{eF}_{\mathrm{E}} \mathrm{NO}$ three times in course of one working day. Measurements were performed between 7:00-10:00, 10:00-13:00 and 13:00-16:00. There was at least a two-hour gap between measurements in each subject. The variation of the NO-parameters during the day was evaluated by calculating CV. The differences in parameter means or medians between different times of day were assessed with a repeated measures one-way ANOVA (Greenhouse-Geisser correction was used if the data violated the assumption of sphericity) or non-parametric Friedmans’s 2-way ANOVA by ranks.

Day-to-day variation of the NO-parameters between consecutive days in course of one week $\mathrm{eF}_{\mathrm{E}} \mathrm{NO}$ was measured on 3-5 separate days during one working week and most of the subjects were able to participate on 4 consecutive days. The measurements were performed at the same time daily for each subject 
to overcome possible effects of diurnal variation. The differences in parameter means or medians between different consecutive days were assessed using a generalized linear mixed model, with the measurement session set as a fixed effect factor. Some subjects had only 3 measurements and repeated ANOVA or Friedman's test would have excluded subjects with missing data entirely from the analyses. To compare the day-to-day variation of the two methods used (T\&G and HMA), the mean CV-values obtained by these methods were compared by paired T-test or Wilcoxon’s signed-rank test.

Day-to-day variation was also assessed by calculating variation coefficient: $\mathrm{v}=1.96 \sqrt{2} * S v$, where $\mathrm{Sv}$ is variation standard deviation. $\mathrm{Sv}$ was calculated as: $S v=\sqrt{\sum_{i=1}^{p} S_{i}^{2} / p}$, where $\mathrm{S}_{\mathrm{i}}$ is within-subject standard deviation and $\mathrm{p}$ is number of subjects.

\section{Sample sizes and tests for normality}

Required sample sizes for the study protocols were calculated based on an allowance of $5 \% \alpha$-error and $90 \%$ statistical power in detecting differences between measurements that are 0.25 times the population's standard deviation. Based on this, sample sizes of 22, 11 and 8 subjects were aimed for in testing repeatability, with-inday and day-to-day variation, respectively. Shapiro-Wilk's test was deployed to test for the normality of the parameters. All statistical analysis was calculated using IBM SPSS. NO-parameters were calculated using Microsoft Excel. Bland-Altman -plots were drawn with R package "blandr" [22].

\section{Results}

Altogether, 28 subjects participated in this study and most of them participated in more than one protocol. Subjects were mostly young adults (subject characteristics in Table 1). Ambient air NO-concentration was on average $0.47 \pm 0.56 \mathrm{ppb}$ and free of within-day variation and $2.5 \mathrm{ppb}$ at highest during the measurements included in analyses. On one occasion ambient air NO-concentration was $114 \mathrm{ppb}$ but results obtained on that day were excluded from the analyses.

Table 1. Subject characteristics.

\begin{tabular}{llll}
\hline Variables & $\begin{array}{l}\text { Repeatability } \\
\text { between two } \\
\text { consecutive } \\
\text { measurements }\end{array}$ & $\begin{array}{l}\text { Within-day } \\
\text { variation }\end{array}$ & $\begin{array}{l}\text { Day-to-day } \\
\text { variation }\end{array}$ \\
\hline $\mathbf{n ~ ( m / f )}$ & $25(16 / 9)$ & $14(9 / 5)$ & $13(8 / 5)$ \\
Age (years)* & $2420-64$ & $2321-50$ & $2420-34$ \\
Height (cm) & $174 \pm 9.98$ & $175 \pm 10.6$ & $177 \pm 8.9$ \\
Weight (kg) & $71.0 \pm 9.50$ & $72 \pm 10.5$ & $70.9 \pm 10.1$ \\
\hline
\end{tabular}

*Age presented as median min-max, other variables as mean \pm SD

\section{Repeatability between two consecutive eFENO-measurements}

$\mathrm{J}_{\mathrm{aw}} \mathrm{NO}$ and single $\mathrm{F}_{\mathrm{E}} \mathrm{NO}$-values were most repeatable regarding the within-subject $\mathrm{CV}$-values (Table 2). CV of $\mathrm{J}_{\mathrm{aw}} \mathrm{NO}$ was smallest among the parameters calculated with both methods (HMA and T\&G). CV of $\mathrm{D}_{\mathrm{aw}} \mathrm{NO}$ and $\mathrm{C}_{\mathrm{aw}} \mathrm{NO}$ were notably higher than $\mathrm{CV}$ of the other parameters. There was no statistically significant difference in repeatability of the NO parameters between the two mathematical methods (HMA and T\&G) based on within-subject CVs obtained $\left(\mathrm{J}_{\mathrm{aw}} \mathrm{NO} \mathrm{p}=0.741, \mathrm{C}_{\mathrm{A}} \mathrm{NO} \mathrm{p}=0.058\right)$. Also, CR related to measured means was distinctly smaller in $\mathrm{J}_{\text {aw }} \mathrm{NO}$ compared to the other parameters.

$\mathrm{C}_{\mathrm{A}} \mathrm{NO}$ was on average higher at the second measurement $(\mathrm{T} \& \mathrm{G} \mathrm{p}=0.017$, HMA $\mathrm{p}=0.028)$. $\mathrm{J}_{\mathrm{aw}} \mathrm{NO}$ showed also an increasing trend between the two measurements, but the difference was not statistically significant. $\mathrm{F}_{\mathrm{E}} \mathrm{NO}_{10}$ and $\mathrm{F}_{\mathrm{E}} \mathrm{NO}_{400}$ were also statistically significantly higher during the second measurement $(\mathrm{p}=0.001, \mathrm{p}$ 
$<0.001$ ). Figures 1 and 2 present the Bland-Altman plots for the repeatability of the parameters and eFigure 1 in e-supplement present these for single $\mathrm{F}_{\mathrm{E}} \mathrm{NO}$-values.

Table 2. Repeatability of the NO-parameters between two consecutive $\mathrm{eF}_{\mathrm{E}} \mathrm{NO}$-measurements.

\begin{tabular}{|c|c|c|c|c|c|c|c|}
\hline Parameter & $\mathbf{n}$ & $\begin{array}{l}1 . \\
\text { measurement }\end{array}$ & $\begin{array}{l}2 . \\
\text { measurement }\end{array}$ & p-value & $\begin{array}{l}\text { Within- } \\
\text { subject CV } \text { CV }^{\#}\end{array}$ & $\begin{array}{l}\text { Limits of } \\
\text { agreement* }\end{array}$ & $\mathbf{C R}^{\mathrm{a}}$ \\
\hline $\mathbf{J}_{\mathrm{aw}} \mathbf{N O}_{\mathrm{T} \& \mathrm{G}(\mathrm{pl} / \mathrm{s})}$ & 25 & $907 \pm 418$ & $922 \pm 418$ & 0.218 & $4.5 \% \pm 4.7 \%$ & $-154-119$ & 142 \\
\hline $\mathrm{C}_{\mathrm{A}} \mathrm{NO}_{\mathrm{T} \& \mathrm{G}(\mathrm{ppb})}$ & 25 & $1.22(0.98-2.00)$ & 1.57 (1.19-1.92) & $0.017 \dagger$ & $9.6 \% \pm 7.7 \%$ & $-0.76-0.41$ & 0.729 \\
\hline $\mathbf{J}_{\text {aw }} \mathbf{N} \mathbf{O}_{\text {HMA }(p l / s)}$ & 21 & $850 \pm 397$ & $864 \pm 383$ & 0.526 & $4.5 \% \pm 2.9 \%$ & $-173-144$ & 157 \\
\hline $\mathrm{C}_{\mathrm{A}} \mathrm{NO}_{\mathrm{HMA}(\mathrm{ppb})}$ & 21 & $1.14(0.83-1.73)$ & $1.26(0.97-1.95)$ & $0.028 \dagger$ & $13.7 \% \pm 14.3 \%$ & $-1.15-0.71$ & 1.00 \\
\hline $\mathrm{C}_{\mathrm{aw}} \mathrm{NO}_{\mathrm{HMA} \mathrm{(ppb)}}$ & 21 & 115 (79.9-124) & 138 (97.2-215) & 0.073 & $14.9 \% \pm 12.2 \%$ & $-259-178$ & 227 \\
\hline $\begin{array}{l}\mathbf{D}_{\mathrm{aw}} \mathrm{NO}_{\mathrm{HMA}} \\
(\mathrm{pl} / \mathrm{s} / \mathbf{p p b})\end{array}$ & 21 & $7.28 \pm 3.46$ & $6.80 \pm 4.04$ & 0.280 & $17.0 \% \pm 14.5 \%$ & $-4.92-5.88$ & 5.36 \\
\hline $\mathrm{F}_{\mathrm{E}} \mathrm{NO}_{10(\mathrm{ppb})}$ & 23 & $66.6 \pm 31.5$ & $70.5 \pm 33.4$ & $0.001 \dagger$ & $3.6 \% \pm 2.4 \%$ & $-13.0-5.21$ & 11.7 \\
\hline $\mathrm{F}_{\mathrm{E}} \mathrm{NO}_{50}(\mathrm{ppb})$ & 25 & $19.4 \pm 8.58$ & $19.8 \pm 8.27$ & 0.175 & $3.4 \% \pm 3.0 \%$ & $-3.32-2.49$ & 2.96 \\
\hline $\mathrm{F}_{\mathrm{E}} \mathrm{NO}_{400}(\mathrm{ppb})$ & 25 & $3.83 \pm 1.46$ & $4.03 \pm 0.339$ & $<0.001 \dagger$ & $3.9 \% \pm 3.3 \%$ & $-0.66-0.27$ & 0.601 \\
\hline
\end{tabular}
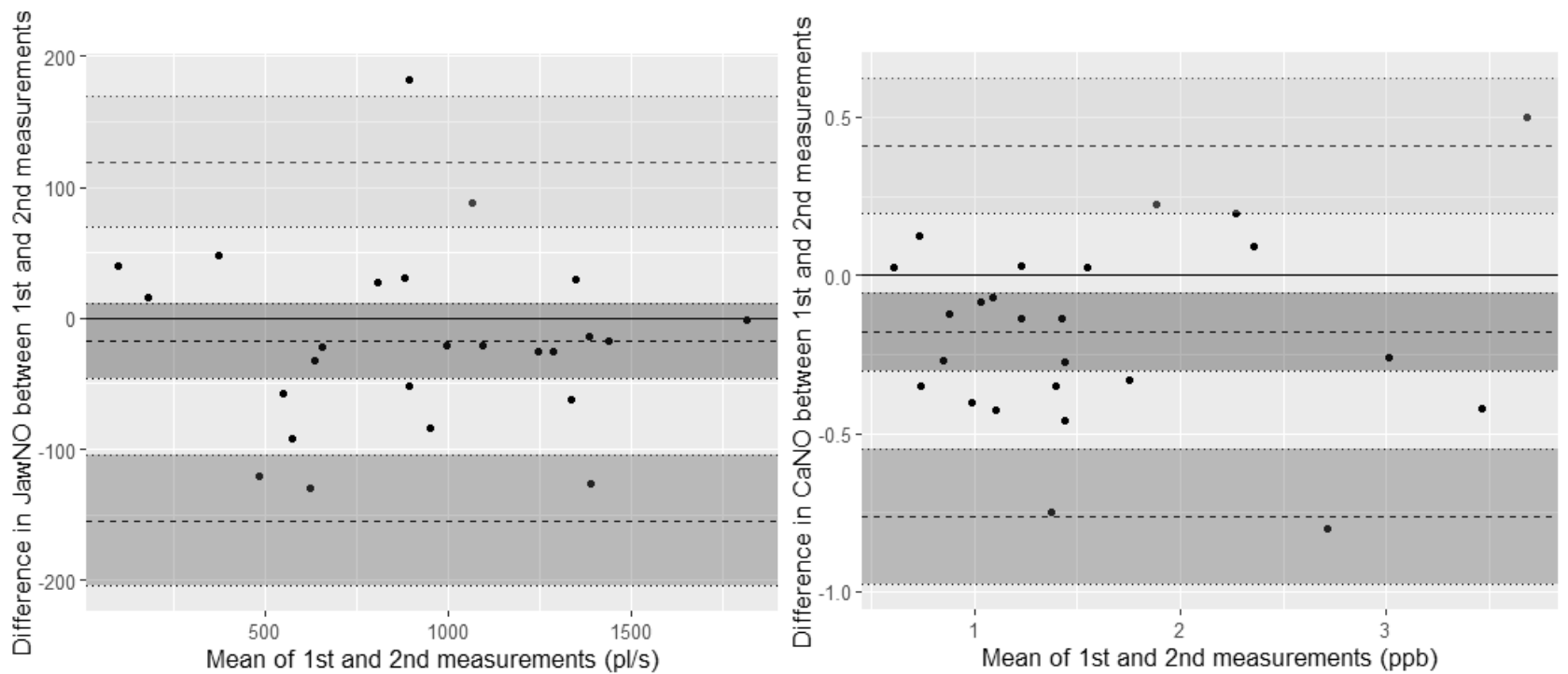

Figure 1. Bland-Altman plots of $\mathrm{C}_{\mathrm{A}} \mathrm{NO}$ and $\mathrm{J}_{\mathrm{aw}} \mathrm{NO}$ from two consecutive measurements using $\mathrm{T} \& \mathrm{G}$-method. 

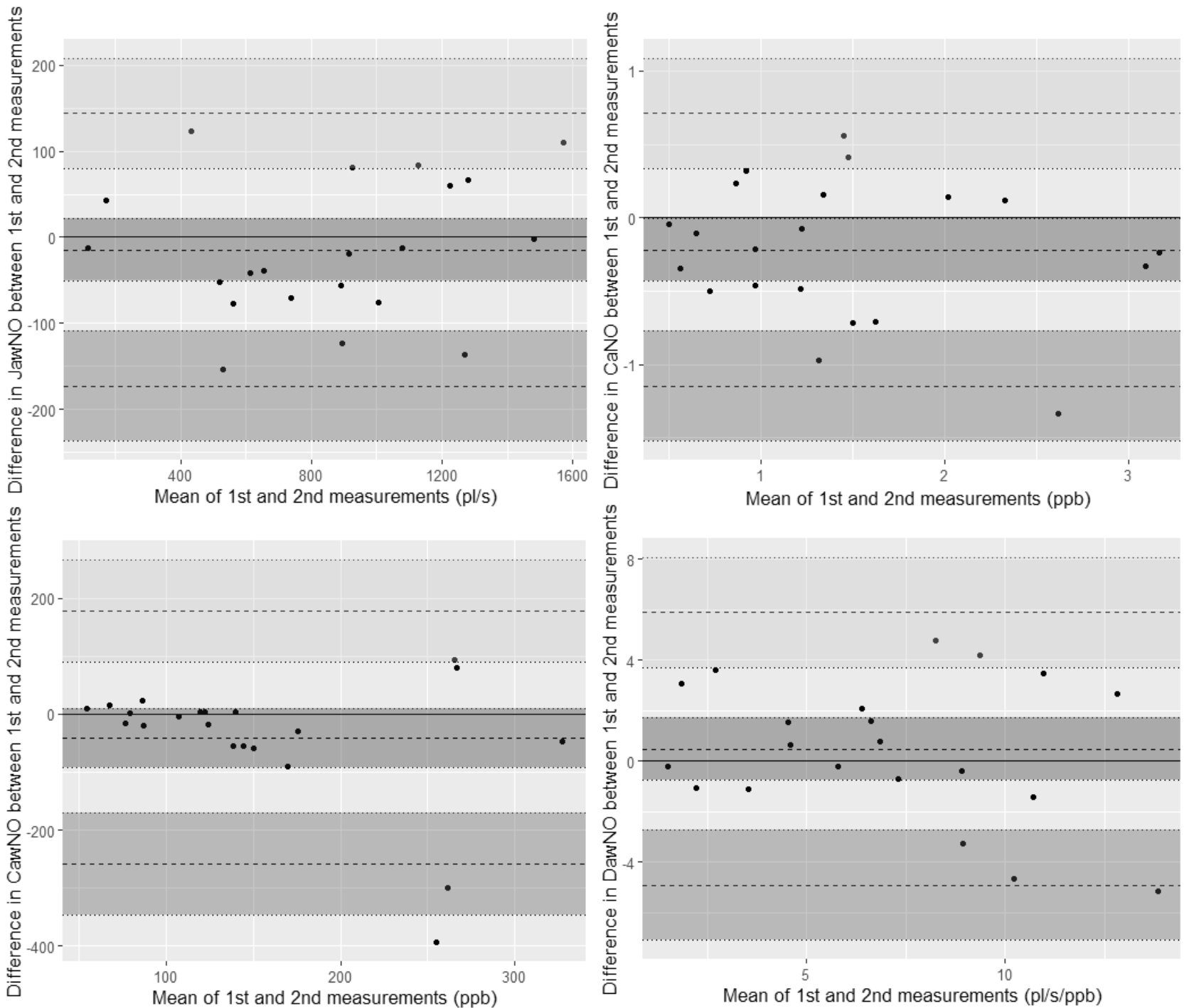

Figure 2. Bland-Altman plots of $\mathrm{J}_{\mathrm{aw}} \mathrm{NO}, \mathrm{C}_{\mathrm{A}} \mathrm{NO}, \mathrm{C}_{\mathrm{aw}} \mathrm{NO}$ and $\mathrm{D}_{\mathrm{aw}} \mathrm{NO}$ from two consecutive measurements using HMA-method.

Within-day-variation of the NO-parameters over a working day

A small but statistically significant increase was observed in $\mathrm{J}_{\mathrm{aw}} \mathrm{NO}$ during a working day. $\mathrm{J}_{\mathrm{aw}} \mathrm{NO}$ was $166 \mathrm{pl} / \mathrm{s}$ higher in afternoon compared to morning ( $p=0.024)$ with the T\&G-method and $223 \mathrm{pl} / \mathrm{s}$ with the HMAmethod ( $p=0.023)$. There were no significant differences in other calculated NO-parameters between different times of day (Table 3 and Figures 3-4). $\mathrm{F}_{\mathrm{E}} \mathrm{NO}_{10}$ was also increased in the afternoon compared to morning ( $\mathrm{F}_{\mathrm{E}} \mathrm{NO}$-values presented in eFigure 2). 
Table 3. Diurnal variation of the NO-parameters over a working day.

\begin{tabular}{|c|c|c|c|c|c|c|}
\hline Parameter & $\mathbf{n}$ & $\begin{array}{l}\text { Morning } \\
\text { (7:00 to } \\
\text { 10:00) }\end{array}$ & $\begin{array}{l}\text { Noon (10:00 } \\
\text { to } 13: 00)\end{array}$ & $\begin{array}{l}\text { Afternoon } \\
(13: 00 \text { to } \\
16: 00)\end{array}$ & $\begin{array}{l}\text { p- } \\
\text { value }^{a}\end{array}$ & $\begin{array}{l}\text { Within } \\
\text { subject CV }\end{array}$ \\
\hline $\mathrm{J}_{\mathrm{aW}} \mathrm{NO}_{\mathrm{T} \& \mathrm{G}(\mathbf{p} / \mathrm{s})}$ & 12 & $716 \pm 387$ & $819 \pm 458$ & $881 \pm 425$ & $0.01 \dagger$ & $13.7 \% \pm 6.7 \%$ \\
\hline $\mathrm{C}_{\mathrm{A}} \mathrm{NO}_{\mathrm{T} \& \mathrm{G}}(\mathbf{p p b})$ & 12 & $1.90 \pm 0.81$ & $1.68 \pm 0.70$ & $1.90 \pm 0.66$ & 0.387 & $16.0 \% \pm 10.8 \%$ \\
\hline $\mathrm{J}_{\text {aw }} \mathrm{NOHмA} \mathrm{(pl/s)}$ & 12 & $781 \pm 344$ & $939 \pm 425$ & $1005 \pm 389$ & $0.005 \dagger$ & $14.3 \% \pm 7.3 \%$ \\
\hline $\mathrm{C}_{\mathrm{A}} \mathrm{NO}_{\text {Hма (ppb) }}$ & 12 & $1.62 \pm 0.86$ & $1.15 \pm 0.54$ & $1.40 \pm 0.72$ & 0.236 & $35.8 \% \pm 17.7 \%$ \\
\hline $\mathrm{C}_{\mathrm{aw}} \mathrm{NO}_{\text {нма (ppb) }}$ & 12 & 13594.1183 & 143 73.5/208 & $12685.9 / 299$ & 0.920 & $29.4 \% \pm 20.5 \%$ \\
\hline $\begin{array}{l}\mathrm{D}_{\mathrm{aw}} \mathrm{NO}_{\text {нмA }} \\
\text { (p//s/ppb) }\end{array}$ & 12 & $5.203 .20 / 8.40$ & 5.93 3.53/7.78 & $5.904 .65 / 12.32$ & 0.205 & $30.3 \% \pm 14.6 \%$ \\
\hline $\mathrm{F}_{\mathrm{E}} \mathrm{NO}_{10}(\mathbf{p p b})$ & 14 & $59.0 \pm 27.6$ & $65.9 \pm 34.3$ & $69.0 \pm 32.8$ & $0.038 \dagger$ & $10.2 \% \pm 5.8 \%$ \\
\hline $\mathrm{F}_{\mathrm{E}} \mathrm{NO}_{50}(\mathrm{ppb})$ & 14 & $16.7 \pm 7.9$ & $18.5 \pm 9.3$ & $19.7 \pm 8.7$ & 0.051 & $9.0 \% \pm 7.4 \%$ \\
\hline $\mathrm{F}_{\mathrm{E}} \mathrm{NO}_{400}(\mathbf{p p b})$ & 14 & $3.49 \pm 1.33$ & $3.49 \pm 1.38$ & $3.71 \pm 1.23$ & 0.366 & $9.8 \% \pm 4.6 \%$ \\
\hline
\end{tabular}

$a$ overall $p$-value, $\dagger \mathrm{p}<0.05$, results reported as mean \pm SD or median 1.st/3.rd interquartile range
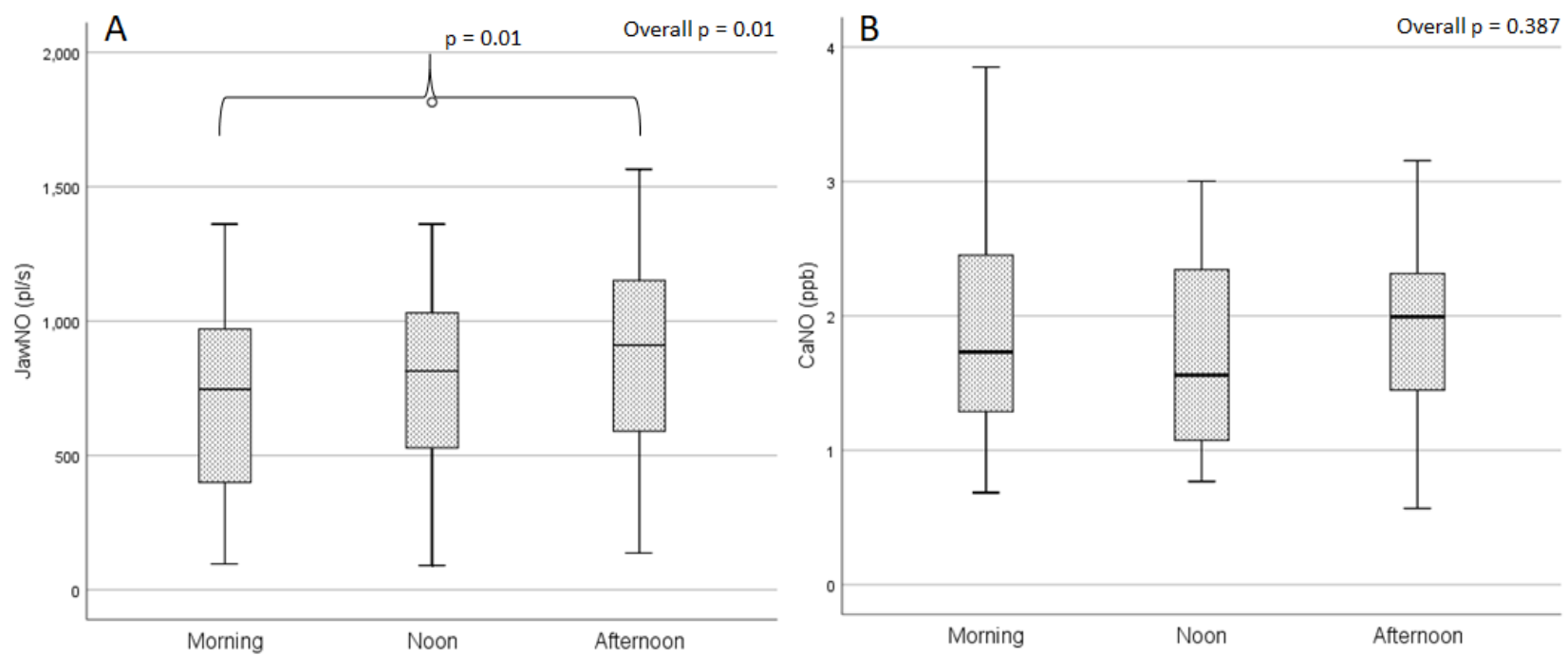

Figure 3. Diurnal variation of the NO-parameters calculated with T\&G-method. 

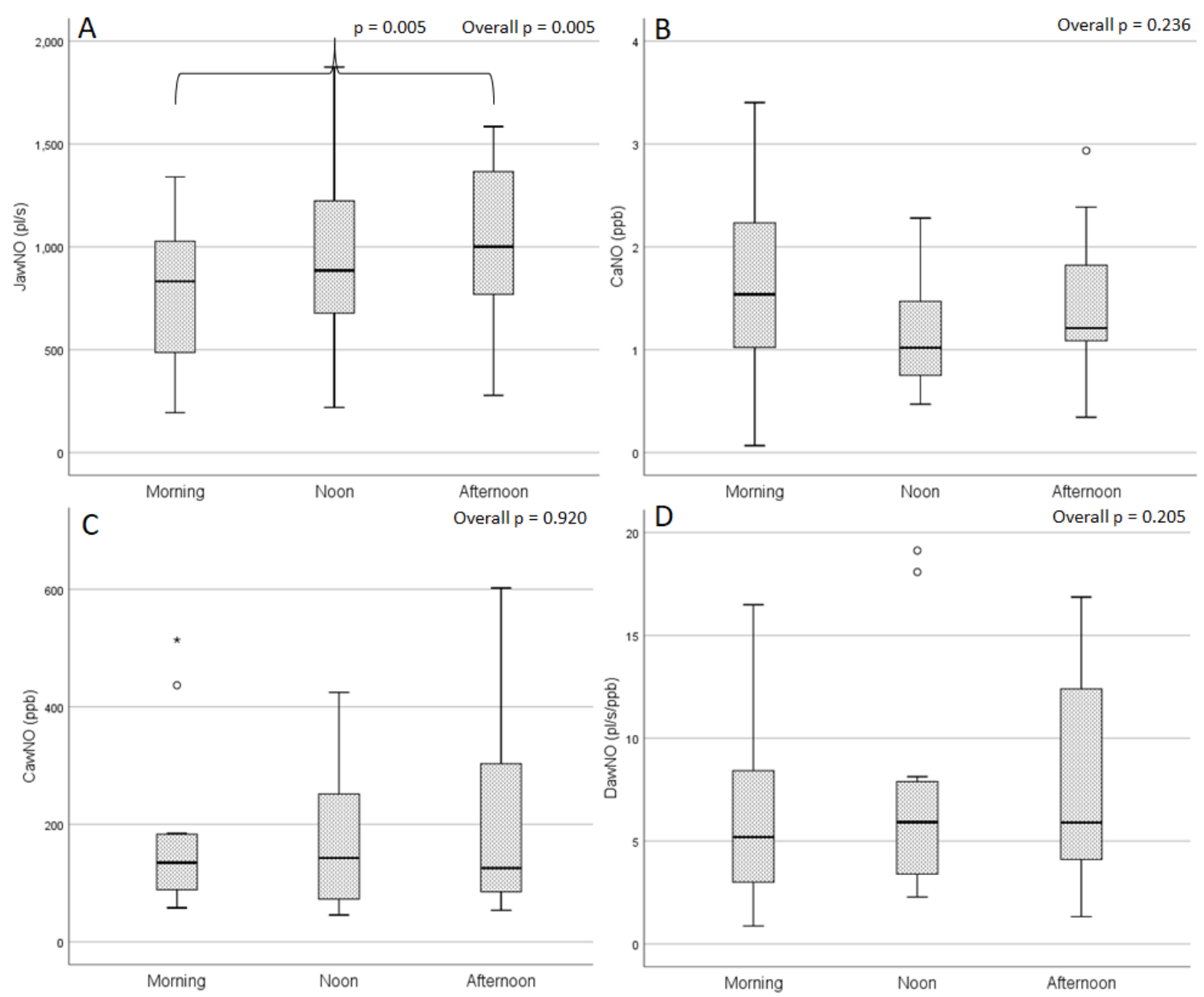

Figure 4. Diurnal variation of the NO-parameters calculated with HMA-method.

Day-to-day variation of the NO-parameters between consecutive days in course of one working week

No statistically significant difference was observed in any calculated NO-parameters between the measurements at consecutive days (Table 4, e-Figure 3-5). Naturally, the within-subject CV-values seemed clearly higher compared to the short-time study protocols, especially when HMA was used to calculate the parameters. HMA yielded significantly higher within-subject $C V$-values for $\mathrm{C}_{\mathrm{A}} \mathrm{NO}$ than $\mathrm{T} \& \mathrm{G}(\mathrm{p}=0.001)$ but the within-subject $C V$-values of $\mathrm{J}_{\mathrm{aw}} \mathrm{NO}$ showed no difference $(\mathrm{p}=0.285)$. Variation coefficient of $\mathrm{J}_{\mathrm{aw}} \mathrm{NO}$ was clearly smallest when compared to its mean. On the other hand, variation coefficients of $\mathrm{D}_{\mathrm{aw}} \mathrm{NO}$ and $\mathrm{C}_{\mathrm{aw}} \mathrm{NO}$ were even larger than their mean values. Variation coefficients seemed smaller when the parameters were calculated using the T\&G-method (295 vs $397 \mathrm{pl} / \mathrm{s}, 1.17 \mathrm{vs} 1.20 \mathrm{ppb}$ ). 
Table 4. Day-to-day variation of the NO-parameters.

\begin{tabular}{|c|c|c|c|c|}
\hline Variables & $\mathbf{n}$ & $\begin{array}{l}\text { Within- } \\
\text { subject CV }\end{array}$ & $\begin{array}{l}\text { Mean of all } \\
\text { days }\end{array}$ & $\begin{array}{l}\text { Variation } \\
\text { coefficient }^{*}\end{array}$ \\
\hline $\mathbf{J}_{\mathrm{aw}} \mathbf{N O}_{\mathrm{T} \& \mathrm{G}}$ & 13 & $15.4 \% \pm 8.4 \%$ & $767 \mathrm{pl} / \mathrm{s}$ & $295 \mathrm{pl} / \mathrm{s}$ \\
\hline $\mathrm{C}_{\mathrm{A}} \mathbf{N O}_{\mathrm{T} \& \mathrm{G}}$ & 13 & $19.2 \% \pm 11.4 \%$ & $1.6 \mathrm{ppb}$ & $1.17 \mathrm{ppb}$ \\
\hline $\mathbf{J}_{\mathrm{aw}} \mathbf{N} \mathbf{O}_{\mathrm{HMA}}$ & 12 & $16.0 \% \pm 9.3 \%$ & $855 \mathrm{pl} / \mathrm{s}$ & $397 \mathrm{pl} / \mathrm{s}$ \\
\hline $\mathrm{C}_{\mathrm{A}} \mathrm{NO}_{\text {HMA }}$ & 12 & $38.0 \% \pm 21.4 \%$ & $1.02 \mathrm{ppb}$ & $1.20 \mathrm{ppb}$ \\
\hline $\mathrm{C}_{\text {aw }} \mathrm{NO}_{\text {HMA }}$ & 12 & $31.1 \% \pm 13.1 \%$ & $86 \mathrm{ppb}$ & $92.1 \mathrm{ppb}$ \\
\hline $\mathbf{D}_{\text {aw }} \mathbf{N O}_{\text {HMA }}$ & 12 & $36.6 \% \pm 19.0 \%$ & $12.8 \mathrm{pl} / \mathrm{s} / \mathrm{ppb}$ & $15.7 \mathrm{pl} / \mathrm{s} / \mathrm{ppb}$ \\
\hline $\mathrm{F}_{\mathrm{E}} \mathrm{NO}_{10}$ & 13 & $13.0 \% \pm 6.8 \%$ & $53.6 \mathrm{ppb}$ & $21.9 \mathrm{ppb}$ \\
\hline $\mathrm{F}_{\mathbf{E}} \mathrm{NO}_{50}$ & 13 & $9.9 \% \pm 4.0 \%$ & $15.5 \mathrm{ppb}$ & $4.10 \mathrm{ppb}$ \\
\hline $\mathrm{F}_{\mathrm{E}} \mathrm{NO}_{400}$ & 13 & $9.4 \% \pm 5.9 \%$ & $3.08 \mathrm{ppb}$ & $1.12 \mathrm{ppb}$ \\
\hline
\end{tabular}

\section{Discussion}

To develop e $\mathrm{F}_{\mathrm{E}} \mathrm{NO}$-measurement towards clinical applications, it is important to know the repeatability of the method and normal variation of the NO-parameters. In this study we found that repeatability of $\mathrm{eF}_{\mathrm{E}} \mathrm{NO}-$ measurement was good and day-to-day variation of NO-parameters in healthy subjects was quite low. The most repeatable NO-parameter was $\mathrm{J}_{\mathrm{aw}} \mathrm{NO}$, whereas $\mathrm{D}_{\mathrm{aw}} \mathrm{NO}$ and $\mathrm{C}_{\mathrm{aw}} \mathrm{NO}$ were notably least repeatable and most variable. No significant difference between the two methods (HMA and T\&G) was observed when comparing their repeatability. A small difference was observed between the morning and afternoon $\mathrm{J}_{\mathrm{aw}} \mathrm{NO}$-values, but the other parameters showed no significant change during one working day. As might be expected, no differences between the consecutive days during working week were discovered.

Repeatability

$\mathrm{C}_{\mathrm{A}} \mathrm{NO}, \mathrm{F}_{\mathrm{E}} \mathrm{NO}_{10}$ and $\mathrm{F}_{\mathrm{E}} \mathrm{NO}_{400}$ were on average higher at the latter consecutive $\mathrm{F}_{\mathrm{E}} \mathrm{NO}$-measurement, while there was no such difference in other NO-parameters. One explanation for the increase in $\mathrm{C}_{\mathrm{A}} \mathrm{NO}, \mathrm{F}_{\mathrm{E}} \mathrm{NO}_{10}$ and $\mathrm{F}_{\mathrm{E}} \mathrm{NO}_{400}$ during the second measurement is that they all involve the most challenging flow rates for the subject: $\mathrm{F}_{\mathrm{E}} \mathrm{NO}_{10}$ requiring the longest steady blow and $\mathrm{F}_{\mathrm{E}} \mathrm{NO}_{400}$ usually requiring emptying one's lung capacity to the most. The problem with the flow rates that require emptying one's lung capacity to the most is that the $\mathrm{F}_{\mathrm{E}} \mathrm{NO}$ vs time curve does not always reach a steady plateau but instead may form a declining profile. Estimating plateau becomes more inaccurate and if the subject was fatigued during the latter measurement and performing shorter blows, estimated $\mathrm{F}_{\mathrm{E}} \mathrm{NO}$-plateau could have been higher. Calculation of $\mathrm{C}_{\mathrm{A}} \mathrm{NO}$ is highly dependent on $\mathrm{F}_{\mathrm{E}} \mathrm{NO}$ at the highest flow rate used and the above mentioned phenomenon may have resulted in higher $\mathrm{C}_{\mathrm{A}} \mathrm{NO}$ during the second measurement.

Ascending or descending of the $\mathrm{F}_{\mathrm{E}} \mathrm{NO}$-plateau as the subject fatigues depends on the shape of the $\mathrm{F}_{\mathrm{E}} \mathrm{NO}$ vs time curve. If the curve is declining in profile, the plateau of $\mathrm{F}_{\mathrm{E}} \mathrm{NO}$ remains at higher level as subject fatigues and performs shorter blows. We often noticed $\mathrm{F}_{\mathrm{E}} \mathrm{NO}$ vs time -curve to be declining in the higher flow rates. This is because as the subject begins to blow, higher NO levels from the oropharynx and upper airways create a peak in the beginning of the NO-curve. When subject exhales through the mouthpiece, air from less NO-rich peripheral part of the lung dilutes the NO-concentration, creating a declining curve finally reaching a steady plateau. However, this applies better for the higher flow rates when measured $\mathrm{F}_{\mathrm{E}} \mathrm{NO}$ is low and could explain increase in $\mathrm{C}_{\mathrm{A}} \mathrm{NO}$ as calculation of $\mathrm{C}_{\mathrm{A}} \mathrm{NO}$ is highly dependent on $\mathrm{F}_{\mathrm{E}} \mathrm{NO}$ measured at the higher flow rates.

$\mathrm{J}_{\mathrm{aw}} \mathrm{NO}$ was most repeatable among the NO-parameters. This may be due to that $\mathrm{J}_{\mathrm{aw}} \mathrm{NO}$ is calculated using the easily performed flow rates (100-400 ml/s) and it shows least variation when different combinations of flow rates are used [10] and thus one unsuccessful measurement point may not have had such significant effect on 
$\mathrm{J}_{\mathrm{aw}} \mathrm{NO}$. This could explain why a significant increase in $\mathrm{J}_{\mathrm{aw}} \mathrm{NO}$ was not observed even if elevated $\mathrm{C}_{\mathrm{A}} \mathrm{NO}$ was caused by fatigued subjects. On the other hand, $\mathrm{D}_{\mathrm{aw}} \mathrm{NO}$ and $\mathrm{C}_{\mathrm{aw}} \mathrm{NO}$ were the least repeatable as calculation of these depend heavily on $\mathrm{F}_{\mathrm{E}} \mathrm{NO}$ measured at the low flow rates (10 ml/s in this study).

No statistically significant difference was observed in repeatability between the compared methods. However, CVs of $\mathrm{C}_{\mathrm{A}} \mathrm{NO}$ were almost statistically significantly higher with HMA compared to T\&G ( $\left.p=0.058\right)$. We believe that the reason behind this lies in the number of used measurement points in the parameter calculation. HMA uses 3 flow rates whereas T\&G uses 4 in this study. With less measurement points, inaccuracy in the parameter estimation increases, possibly explaining the higher $\mathrm{CV}$ values. Secondly, $\mathrm{C}_{\mathrm{A}} \mathrm{NO}$ was less repeatable compared to $\mathrm{J}_{\mathrm{aw}} \mathrm{NO}$ with both estimation methods.

In this study, the subjects were mostly young, healthy and well cooperative. Nevertheless, the $\mathrm{F}_{\mathrm{E}} \mathrm{NO}$ measurements were sometimes found challenging to perform, especially the extremely low and high flow rates. The low flow rates $(10-20 \mathrm{ml} / \mathrm{s})$ seemed to cause most difficulties. The low flow rates required sometimes long periods (up to 60 seconds) of slow and steady exhalation and subjects run out of breath before reaching a steady plateau. Sometimes subjects found it difficult to keep their tongue and pharynx steady during the low flow rates. Movement of tongue caused peak in the $\mathrm{F}_{\mathrm{E}} \mathrm{NO}$ vs time -curve and it hindered the formation of a steady plateau. Some subjects had also problems with the highest flow rate $(400 \mathrm{ml} / \mathrm{s})$. This was probably due to the lack of enough lung capacity for steady plateau to form. Subjects felt fatigued especially during the low flow rates of the second consecutive measurement and sometimes air tended to leak between lips and mouth piece. These problems emerge especially in a research protocol like this where two consecutive series of $\mathrm{eF}_{\mathrm{E}} \mathrm{NO}$-measurements with 8 flows are done. In clinical use, one $\mathrm{eF}_{\mathrm{E}} \mathrm{NO}$-measurement with less flows is surely easier for subjects to perform.

The latest technical standard on $\mathrm{F}_{\mathrm{E}} \mathrm{NO}$ measurement suggests using HMA and T\&G methods for calculating NO parameters. These methods require flow rates of 10,100 and $400 \mathrm{ml} / \mathrm{s}$, and $100-400 \mathrm{ml} / \mathrm{s}$, respectively. As this study was originally designed and initiated before the publication of the ERS technical standard, we had included also flow rates of 20 and $30 \mathrm{ml} / \mathrm{s}$ to the protocol. These were among the most challenging flow rates for subjects to perform and they unnecessarily exhausted the subjects and may have increased variation to the results.

To our knowledge, this is the first study investigating short time repeatability of the NO-parameters in healthy subjects. $\mathrm{F}_{\mathrm{E}} \mathrm{NO}_{50}$-measurement has already been investigated and it is known to be highly repeatable [23], reproducible and free of within-day and day-to-day variation [23,24].

\section{Within-day variation}

We observed a small increase in $\mathrm{J}_{\mathrm{aw}} \mathrm{NO}$ towards afternoon. We can only speculate the reason for increase in $\mathrm{J}_{\mathrm{aw}} \mathrm{NO}$ during a working day in this study. $\mathrm{J}_{\mathrm{aw}} \mathrm{NO}$ is determined by $\mathrm{C}_{\mathrm{aw}} \mathrm{NO}$ and $\mathrm{D}_{\mathrm{aw}} \mathrm{NO}$, of which both showed a mild but not significant increase during the day. Possible increase in $\mathrm{C}_{\mathrm{aw}} \mathrm{NO}$ might be related to circadian rhythm of cortisol level (NO synthesis by iNOS is downregulated by glucocorticoids [25]) and the peak for cortisol secretion is about at the time of waking up [26]. Also, daytime exposure to different inhaled irritants might trigger inflammatory responses in airway epithelium and traffic related air pollutants are known to cause inflammation in peripheral airways and increased $\mathrm{C}_{\mathrm{A}} \mathrm{NO}$-levels [27]. Other possible biological explanations could be related to subjects' diet. Up to $89 \%$ increased $\mathrm{F}_{\mathrm{E}} \mathrm{NO}$-levels are measured after nitrate rich meal and half of the subjects had increased $\mathrm{F}_{\mathrm{E}} \mathrm{NO}$-levels even 3 hours after the meal [28]. Oral sodium nitrate intake has been noticed to increase NO-parameters $\mathrm{J}_{a w} \mathrm{NO}$ and $\mathrm{C}_{\mathrm{A}} \mathrm{NO}$ [29]. In this study, we instructed the subject to refrain from eating at least 1 hour prior the measurement. Chlorhexidine wash is noticed to lower $\mathrm{J}_{\text {aw }} \mathrm{NO}$ and normalize $\mathrm{C}_{\mathrm{A}} \mathrm{NO}$ after nitrate intake [29] but in this study, we used water for mouth wash prior the measurement. Day-time nitrate intake is one potential factor explaining our findings. Finnish breakfast usually consists of carbohydrate rich food (e.g. porridge, bread) low on nitrates. Nitrate intake during lunch may have increased the afternoon $\mathrm{F}_{\mathrm{E}} \mathrm{NO}$ and thus $\mathrm{J}_{\mathrm{aw}} \mathrm{NO}$ levels. Changes in $\mathrm{D}_{\mathrm{aw}} \mathrm{NO}$ are more complex since $\mathrm{D}_{\mathrm{aw}} \mathrm{NO}$ is determined by both physical diffusivity of NO in airway mucosa and also the surface area of airway mucosa contributing to NO production [5]. Theoretically the same inhaled irritants that trigger inflammatory activity 
to enhance NO production might increase $\mathrm{D}_{\mathrm{aw}} \mathrm{NO}$ by activating iNOS also in more peripheral parts of airways and by increasing the surface area of NO production.

In addition to biological explanations, there is also theoretical possibility of calibration drift. However, we consider this quite unlikely. Ambient air NO-concentration was very low $(0.47 \pm 0.56 \mathrm{ppb})$ and was free of diurnal variation. Theoretically, ambient air NO could have decreased during the day, masking upward calibration drift. However, the NO-concentration in the morning was so low that possible decrease in ambient air NO during the day would be insufficient to mask such high calibration drift causing the observed increase in the NO-parameters.

To our knowledge, there are only a few studies investigating diurnal variation of the NO-parameters in healthy subjects. Brindicci et al. observed no significant diurnal variation in the NO-parameters, but the sample size was relatively small $(n=9)$ [11]. In another study, asthmatics were mixed with healthy subjects but still no significant diurnal variation was observed [12]. On the other hand, Duong et al. noticed a significant increase in $\mathrm{C}_{\mathrm{A}} \mathrm{NO}$ and $\mathrm{F}_{\mathrm{E}} \mathrm{NO}_{50}$ between 8 p.m. and 6. a.m. of the day after [13]. Circadian variation of $\mathrm{F}_{\mathrm{E}} \mathrm{NO}_{50}$ has been investigated in more detail in healthy and asthmatic subjects and no statistically significant variation has been observed [24,30-32]. In these studies, $\mathrm{F}_{\mathrm{E}} \mathrm{NO}_{50}$ seems to have a decreasing trend during the day. Circadian variation in healthy subjects' sputum and blood eosinophils have also been studied but no significant variation has been observed [33].

According to our results, it would be recommended to schedule $\mathrm{eF}_{\mathrm{E}} \mathrm{NO}$-measurements at the same time of day for each patient in future studies to overcome the possible bias caused by normal within-day variation. Scheduling of the $\mathrm{eF}_{\mathrm{E}} \mathrm{NO}$-measurement becomes especially important if $\mathrm{eF}_{\mathrm{E}} \mathrm{NO}$-measurement would be used to follow up treatment responses. However, the possible normal diurnal rhythm of the NO-parameters still needs to be further studied as the current literature has somewhat conflicting results.

\section{Day-to-day variation}

As expected, day-to-day variation seemed notably higher than the variation of two consecutive measurements. $\mathrm{J}_{\mathrm{aw}} \mathrm{NO}$ among single $\mathrm{F}_{\mathrm{E}} \mathrm{NO}$-values had least day-to-day variation compared to other parameters. $\mathrm{D}_{\mathrm{aw}} \mathrm{NO}$ and $\mathrm{C}_{\mathrm{aw}} \mathrm{NO}$ had relatively high variation coefficients, and thereby changes in these variables in subjects with pulmonary disease need to be quite large to be differentiated from normal variation. $\mathrm{J}_{\mathrm{aw}} \mathrm{NO}$ and $\mathrm{C}_{\mathrm{A}} \mathrm{NO}$ on the other hand had lower variation coefficients, making these more usable for clinical use. $\mathrm{CV}$ for $\mathrm{C}_{\mathrm{A}} \mathrm{NO}$ seemed clearly higher with HMA compared to T\&G. We believe that the amount of measurement points explains differences between these methods' CVs as discussed above. In clinical practice the method should be selected based on whether interest lies on JawNO and CaNO only (T\&G is enough and may have less variation regarding CaNO) or if also CawNO and DawNO are needed (HMA should be used). No differences were observed in average values of the NO parameters between the consecutive days. To our knowledge, day-today variation of the NO-parameters has not been previously studied. However, $\mathrm{F}_{\mathrm{E}} \mathrm{NO}$ measurements have been noticed to have low variability when measured in 6 consecutive days in both healthy and asthmatic subjects [34].

Variation of the NO-parameters over varying time scales have been investigated in multiple studies. They all state that all the NO-parameters have little variation over time and it seems that $\mathrm{J}_{\mathrm{aw}} \mathrm{NO}$ has least variation, whereas $\mathrm{C}_{\mathrm{A}} \mathrm{NO}$ and the other parameters show greater variation over time [11,12,15-17,35]. Some studies investigated only $\mathrm{C}_{\mathrm{A}} \mathrm{NO}$ and the variation was shown to be low $[14,36]$. Single $\mathrm{F}_{\mathrm{E}} \mathrm{NO}$-values seemed less variable than the NO-parameters and this is possibly due to that the NO-parameters are calculated from multiple $\mathrm{F}_{\mathrm{E}} \mathrm{NO}$-measurements and inaccuracy accumulates when multiple measurement points, each having their own random error, are used. This is especially an issue with $\mathrm{D}_{\mathrm{aw}} \mathrm{NO}$ and $\mathrm{C}_{\mathrm{aw}} \mathrm{NO}$ that are calculated based on an exponential function.

One potent source of error is that the subjects had different eating and exercise habits prior the measurements in consecutive days and this may have increased the observed inter-day variation. Subjects were instructed to avoid eating and heavily exercise at least one hour prior the $\mathrm{eF}_{\mathrm{E}} \mathrm{NO}$-measurements. Physical exercise is known 
to influence the NO-parameters. Shin et al. found $\mathrm{D}_{\mathrm{aw}} \mathrm{NO}$ to increase, whereas $\mathrm{J}_{\mathrm{aw}} \mathrm{NO}$ and $\mathrm{C}_{\mathrm{A}} \mathrm{NO}$ were decreased after high-intensity exercise [37]. $\mathrm{J}_{\mathrm{aw}} \mathrm{NO}$ and $\mathrm{C}_{\mathrm{A}} \mathrm{NO}$ are also noticed to decrease in marathoners after a marathon run but on the other hand, these marathoners had higher baseline levels of $\mathrm{C}_{\mathrm{A}} \mathrm{NO}$ and $\mathrm{J}_{\mathrm{aw}} \mathrm{NO}$ [38]. There are also studies reporting no change in $\mathrm{F}_{\mathrm{E}} \mathrm{NO}$-levels after exercise [39] and the current literature overall is somewhat conflicting. However, exercise is reported to have both acute and long-term effects on the NOparameters. Acute effects were tried to be minimized by avoiding exercise in one hour prior measurements. In clinical use, patients should be asked about their exercising habits

Some bias may arise from that the subjects learned to perform the $\mathrm{F}_{\mathrm{E}} \mathrm{NO}$-measurement better during the study. This was especially true for the subjects that participated in more than one study protocol and this could be especially noticeable with the extreme flow rates. The possible learning effect may become a problem if the subject performs the $\mathrm{eF}_{\mathrm{E}} \mathrm{NO}$-measurement multiple times and treatment is tailored according to changes in the results or disease progression is monitored with repetitive measurements. However, no difference in average values of the parameters was noticed between the consecutive days, which speaks against the possible learning effect. Kharitonov et al. investigated the learning effect in $\mathrm{F}_{\mathrm{E}} \mathrm{NO}$-measurement but no significant effect was observed [24]. However, asthmatic subjects seemed to have a decreasing trend during the consecutive measurement situations.

\section{Future research}

Preferably our findings on repeatability and normal variation of NO parameters should be confirmed in another study. On top of only verifying the results in healthy subjects, further studies in subjects with different pulmonary diseases are needed to assess the relation between change in NO parameters and change in disease activity or disease progression.

\section{Conclusion}

In conclusion, short-term repeatability of $\mathrm{eF}_{\mathrm{E}} \mathrm{NO}$-measurement was good and day-to-day variation in NOparameters in healthy subjects was quite low. Of the NO-parameters, $\mathrm{J}_{\mathrm{aw}} \mathrm{NO}$ was the most repeatable, whereas $\mathrm{D}_{\mathrm{aw}} \mathrm{NO}$ and $\mathrm{C}_{\mathrm{aw}} \mathrm{NO}$ were notably least repeatable. Both investigated methods (T\&G and HMA) yielded equally repeatable results in short-term, but within-subject $\mathrm{CV}$ for $\mathrm{C}_{\mathrm{A}} \mathrm{NO}$ was higher with HMA than with T\&G. A small difference between morning and afternoon values of $\mathrm{J}_{\mathrm{aw}} \mathrm{NO}$ and $\mathrm{F}_{\mathrm{E}} \mathrm{NO}_{50}$ was observed and if possible, we recommend scheduling repeated $\mathrm{F}_{\mathrm{E}} \mathrm{NO}$-measurements at the same time of day. The upper $95 \%$ limit for normal day-to-day variation in NO parameters was about $1.2 \mathrm{ppb}$ in $\mathrm{C}_{\mathrm{A}} \mathrm{NO}, 400 \mathrm{pl} / \mathrm{s}$ in $\mathrm{J}_{\mathrm{aw}} \mathrm{NO}, 92 \mathrm{ppb}$ in $\mathrm{C}_{\mathrm{aw}} \mathrm{NO}$ or $16 \mathrm{pl} / \mathrm{s} / \mathrm{ppb}$ in $\mathrm{D}_{\mathrm{aw}} \mathrm{NO}$. In clinical use a between-visits change in NO parameters above these limits suggest changes in diseases activity.

\section{Funding}

The study was supported by grants from the Finnish anti-tuberculosis foundation (https://www.tbfoundation.org/), The Research Foundation of the Pulmonary Diseases (https://www.hengitysliitto.fi/fi), Tampere Tuberculosis Foundation (http:/www.tuberkuloosisaatio.fi/), the Competitive State Research Financing of the Expert Responsibility area of Tampere University Hospital and Foundation for Tampere University Hospital (https://taystuki.fi/).

\section{Conflicts of interest}

We declare no conflicts of interest.

\section{References}

[1] ATS/ERS recommendations for standardized procedures for the online and offline measurement of exhaled lower respiratory nitric oxide and nasal nitric oxide, 2005 2005American Journal of Respiratory and Critical Care Medicine 171 912-930. 
[2] Horvath I, Barnes P J, Loukides S, Sterk P J, Hogman M, Olin A, Amann A, Antus B, Baraldi E, Bikov A, et al. 2017 A European Respiratory Society technical standard: exhaled biomarkers in lung disease European Respiratory Journal 491600965.

[3] National Institute for Health and Clinical Excellence. 2017Asthma: diagnosis, monitoring and chronic asthma management.

[4] GINA Report. 2018Global Strategy for Asthma Management and Prevention.

[5] Tsoukias N M, George S C. 1998 A two-compartment model of pulmonary nitric oxide exchange dynamics J.Appl.Physiol.(1985) 85 653-666.

[6] Tsoukias N, Shin H, Wilson A, George S. 2001 A single-breath technique with variable flow rate to characterize nitric oxide exchange dynamics in the lungs J.Appl.Physiol. 91 477-487.

[7] George S C, Hogman M, Permutt S, Silkoff P E. 2004 Modeling pulmonary nitric oxide exchange J.Appl.Physiol. 96 831-839.

[8] Hogman M, Holmkvist T, Wegener T, Emtner M, Andersson M, Hedenstrom H, Merilainen P. 2002 Extended NO analysis applied to patients with COPD, allergic asthma and allergic rhinitis Respir.Med. 96 24-30.

[9] Karvonen T, Kankaanranta H, Saarelainen S, Moilanen E, Lehtimaki L. 2017 Comparison of feasibility and estimates of central and peripheral nitric oxide parameters by different mathematical models J.Breath Res. 11 047102-7163/aa7cc0.

[10] Roy K, Borrill Z L, Starkey C, Hazel A L, Morris J, Vestbo J, Singh D. 2007 Use of different exhaled nitric oxide multiple flow rate models in COPD.European Respiratory Journal 29 651-659.

[11] Brindicci C, Ito K, Resta O, Pride N B, Barnes P J, Kharitonov S A. 2005 Exhaled nitric oxide from lung periphery is increased in COPD.European Respiratory Journal 26 52-59.

[12] Brindicci C, Ito K, Barnes P J, Kharitonov S A. 2007 Differential flow analysis of exhaled nitric oxide in patients with asthma of differing severity.Chest 131 1353-1362.

[13] Duong-Quy S, Hua-Huy T, Tran-Mai-Thi H, Le-Dong N, Craig T J, Dinh-Xuan A. 2016 Study of Exhaled Nitric Oxide in Subjects with Suspected Obstructive Sleep Apnea: A Pilot Study in Vietnam.Pulmonary Medicine 20163050918.

[14] Berry M, Hargadon B, Morgan A, Shelley M, Richter J, Shaw D, Green R, Brightling C, Wardlaw A, Pavord I. 2005 Alveolar nitric oxide in adults with asthma: evidence of distal lung inflammation in refractory asthma European Respiratory Journal 25 986-991.

[15] Brindicci C, Ito K, Barnes P J, Kharitonov S A. 2007 Effect of an inducible nitric oxide synthase inhibitor on differential flow-exhaled nitric oxide in asthmatic patients and healthy volunteers. Chest 132 581-588.

[16] Paraskakis E, Brindicci C, Fleming L, Krol R, Kharitonov S A, Wilson N M, Barnes P J, Bush A. 2006 Measurement of bronchial and alveolar nitric oxide production in normal children and children with asthma.American Journal of Respiratory \& Critical Care Medicine 174 260-267. 
[17] Nicolini G, Chetta A, Simonazzi A, Tzani P, Aiello M, Olivieri D. 2010 Both bronchial and alveolar exhaled nitric oxide are reduced with extrafine beclomethasone dipropionate in asthma.Allergy \& Asthma Proceedings 31 85-90.

[18] Moilanen E, Lehtimäki L. Method and measuring equipment for measuring nitric oxide concentration in exhaled air. US 2002/0193698 A1. 2002.

[19] Linkosalo L, Lehtimaki L, Laitinen J, Kaila M, Holm K, Moilanen E. 2008 Increased bronchial NO output in severe atopic eczema in children and adolescents.Pediatric Allergy \& Immunology 19 426-432.

[20] Hogman M, Holmkvist T, Wegener T, Emtner M, Andersson M, Hedenstrom H, Merilainen P. 2002 Extended NO analysis applied to patients with COPD, allergic asthma and allergic rhinitis Respir.Med. 96 24-30.

[21] Bland J M, Altman D G. 1986 Statistical methods for assessing agreement between two methods of clinical measurement Lancet 1 307-310.

[22] Datta D. 2017blandr: a Bland-Altman Method Comparison package for R. .

[23] Lehtimaki L, Turjanmaa V, Kankaanranta H, Saarelainen S, Hahtola P, Moilanen E. 2000 Increased bronchial nitric oxide production in patients with asthma measured with a novel method of different exhalation flow rates.Ann.Med. 32 417-423.

[24] Kharitonov S A, Gonio F, Kelly C, Meah S, Barnes P J. 2003 Reproducibility of exhaled nitric oxide measurements in healthy and asthmatic adults and children Eur.Respir.J. 21 433-438.

[25] Korhonen R, Lahti A, Hamalainen M, Kankaanranta H, Moilanen E. 2002 Dexamethasone inhibits inducible nitric-oxide synthase expression and nitric oxide production by destabilizing mRNA in lipopolysaccharide-treated macrophages Mol.Pharmacol. 62 698-704.

[26] Kristenson M, Garvin P, Lundberg U. 2011 The Role of Saliva Cortisol Measurement in Health and Disease. .

[27] Eckel S P, Zhang Z, Habre R, Rappaport E B, Linn W S, Berhane K, Zhang Y, Bastain T M, Gilliland F D. 2016 Traffic-related air pollution and alveolar nitric oxide in southern California children.European Respiratory Journal 47 1348-1356.

[28] Olin A C, Aldenbratt A, Ekman A, Ljungkvist G, Jungersten L, Alving K, Toren K. 2001 Increased nitric oxide in exhaled air after intake of a nitrate-rich meal Respir.Med. 95 153-158.

[29] Malinovschi A, Janson C, Holm L, Nordvall L, Alving K. 2009 Basal and induced NO formation in the pharyngo-oral tract influences estimates of alveolar NO levels J.Appl.Physiol.(1985) 106 513-519.

[30] Mattes J, Storm van's Gravesande K, Moeller C, Moseler M, Brandis M, Kuehr J. 2002 Circadian variation of exhaled nitric oxide and urinary eosinophil protein $\mathrm{X}$ in asthmatic and healthy children Pediatr.Res. 51 190-194.

[31] Antosova M, Bencova A, Psenkova A, Herle D, Rozborilova E. 2009 Exhaled nitric oxide - circadian variations in healthy subjects Eur.J.Med.Res. 14 Suppl 4 6-8.

[32] ten Hacken N H, van der Vaart H, van der Mark T W, Koeter G H, Postma D S. 1998 Exhaled nitric oxide is higher both at day and night in subjects with nocturnal asthma Am.J.Respir.Crit.Care Med. 158 902907. 
[33] Durrington H J, Gioan-Tavernier G O, Maidstone R J, Krakowiak K, Loudon A S I, Blaikley J F, Fowler S J, Singh D, Simpson A, Ray D W. 2018 Time of Day Affects Eosinophil Biomarkers in Asthma: Implications for Diagnosis and treatment Am.J.Respir.Crit.Care Med. .

[34] Bohadana A, Michaely J P, Teculescu D, Wild P. 2008 Reproducibility of exhaled nitric oxide in smokers and non-smokers: relevance for longitudinal studies BMC Pulm.Med. 8 4-2466-8-4.

[35] Foley S C, Hopkins N O, Fitzgerald M X, Donnelly S C, McLoughlin P. 2007 Airway nitric oxide output is reduced in bronchiectasis.Respir.Med. 101 1549-1555.

[36] Gelb A F, Taylor C F, Nussbaum E, Gutierrez C, Schein A, Shinar C M, Schein M J, Epstein J D, Zamel N. 2004 Alveolar and airway sites of nitric oxide inflammation in treated asthma.American Journal of Respiratory \& Critical Care Medicine 170 737-741.

[37] Shin H, Rose-Gottron C M, Cooper D M, Hill M, George S C. 2003 Impact of high-intensity exercise on nitric oxide exchange in healthy adults.Medicine \& Science in Sports \& Exercise 35 995-1003.

[38] Thornadtsson A, Drca N, Ricciardolo F, Hogman M. 2017 Increased levels of alveolar and airway exhaled nitric oxide in runners.Ups.J.Med.Sci. 122 85-91.

[39] Scollo M, Zanconato S, Ongaro R, Zaramella C, Zacchello F, Baraldi E. 2000 Exhaled nitric oxide and exercise-induced bronchoconstriction in asthmatic children Am.J.Respir.Crit.Care Med. 161 1047-1050. 